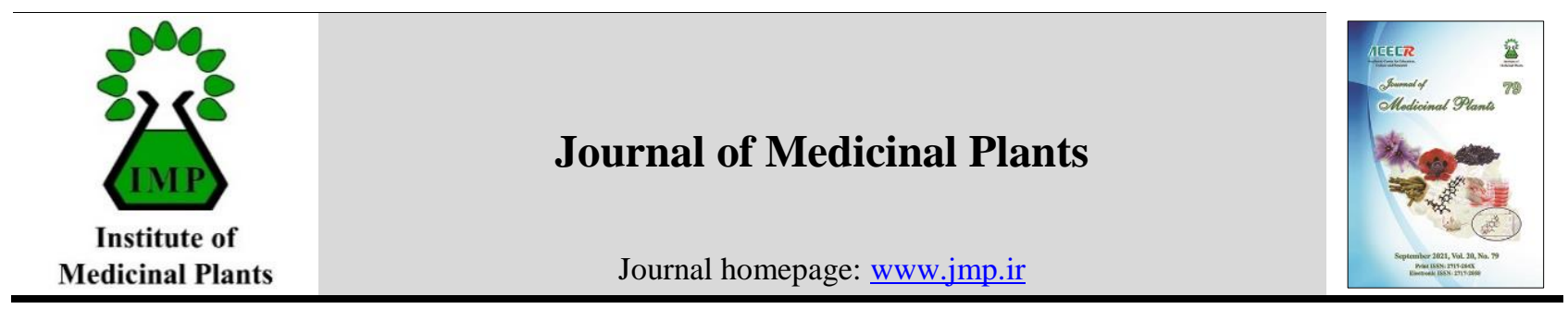

Research Article

\title{
Changes in essential oil composition of peppermint (Mentha $x$ piperita L.) affected by yeast extract and salicylic acid foliar application
}

\author{
Morteza Motiee, Mohammad Abdoli*
}

Department of Plant Production and Genetics, Faculty of Agriculture, Malayer University, Malayer, Iran

\begin{tabular}{|c|c|}
\hline ARTICLE INFO & ABSTRACT \\
\hline $\begin{array}{l}\text { Keywords: } \\
\text { Mentha x piperita } \mathrm{L} \text {. } \\
\text { Elicitor } \\
\text { Secondary Metabolites } \\
\text { Medicinal Plant } \\
\text { Menthone } \\
\text { Menthol }\end{array}$ & $\begin{array}{l}\text { Background: Peppermint (Mentha x piperita L.) is one of the most important medicinal } \\
\text { plants which used in food, pharmaceutical, perfumery, and flavoring industry. } \\
\text { Objective: This study was planned to investigate the effects of foliar application of } \\
\text { salicylic acid and yeast extract on production of valuable essential oil components in } \\
\text { peppermint. Methods: A completely randomized design experiment with nine } \\
\text { treatments consisting salicylic acid }(40,80,160 \text { and } 320 \mathrm{mg} / \mathrm{l}) \text {, yeast extract }(0.25,0.75 \text {, } \\
1 \text { and } 1.5 \mathrm{~g} / \mathrm{l}) \text { and distilled water (control) with three replications was carried out under } \\
\text { greenhouse conditions. Results: In total, forty compounds were identified in the } \\
\text { essential oils of the plant aerial parts. Menthone, menthol, piperitone, isopulegol and } \\
\gamma \text {-terpinene were the major compounds of the oils studied. Menthone and menthol were } \\
16.69 \% \text { and } 14.39 \% \text { of the essential oils, respectively. Salicylic acid and yeast extract } \\
\text { were increased menthone, neomenthol, piperitone, } \gamma \text {-terpinene and isomenthol acetate } \\
\text { production } 42,60,39,59 \text { and } 34 \% \text { higher than control plants, respectively. Foliar } \\
\text { application with } 320 \text { mg/l salicylic acid gave the best result in the enhancement of the } \\
\text { major essential oil components of treated plants. The results of correlation between } \\
\text { essential oil constituents showed that the neomenthol content had a significant positive } \\
\text { correlation with menthone }\left(\mathrm{r}=0.865^{* *}\right), \gamma \text {-terpinene }\left(\mathrm{r}=0.848^{* *}\right) \text { and negative correlation } \\
\left.\text { with isopulegol ( } \mathrm{r}=-0.886^{* *}\right) \text {. Conclusion: The quality of essential oil of } M \text {. piperita } \\
\text { were influenced by the foliar application of salicylic acid and yeast extract at the } \\
\text { appropriate concentrations. Elicitation by } 320 \mathrm{mg} / 1 \text { salicylic acid was the optimum } \\
\text { treatment for menthone, neomenthol, } \gamma \text {-terpinene and piperitone production. }\end{array}$ \\
\hline
\end{tabular}

\section{Introduction}

Secondary metabolites have complex structures to be manufactured by chemical synthesis and thus frequently extracted from naturally grown or cultivated plants [1]. Essential oils are natural complex volatile secondary metabolites that are often obtained from various aromatic plants using the hydro-distillation technique [2]. Peppermint (Mentha x piperita L.), a perennial herbaceous medicinal plant of Lamiaceae family is a natural hybrid from M. aquatica $\times$ M. spicata. The plant is cultivated

\footnotetext{
Abbreviations: GC-MS, Gas chromatography-mass spectrometry; SE, Standard error; C.V., Coefficient of variation

* Corresponding author: Abdoli_m@malayeru.ac.ir
}

doi: $10.52547 / j m p .20 .79 .47$

Received 22 May 2021; Received in revised form 3 August 2021; Accepted 10 August 2021

(C) 2020. Open access. This article is distributed under the terms of the Creative Commons Attribution-NonCommercial 4.0 International License (https://creativecommons.org/licenses/by-nc/4.0/) 
in a temperate region of Europe, Asia, United States, India and Mediterranean countries due to their commercial value and distinct aroma [3]. It is an important medicinal and aromatic herb worldwide, in addition to its potential uses as a flavoring agent, in cosmetics, and pharmaceutical products among others $[4,5]$. Leaves of $M$. piperita contain 1.2-3.9\% (v/w) of essential oils and more than 300 recognized components. The terpenes with about $52 \%$ of monoterpenes and $9 \%$ of sesquiterpenes are the most important components of peppermint leaves [6]. The composition of the essential oil isolated from aerial parts of $M$. piperita has been a subject of extensive studies [3, 7-11]. Peppermint essential oil containing high concentrations of menthol and menthone are used in traditional medicine to treat various conditions including infections and also as insect repellant. Various in vitro and in vivo studies have documented the biological properties of menthol such as its analgesic, antibacterial, antifungal, anaesthetic and penetration-enhancing effects as well as chemopreventive and immunomodulating actions [5, 12]. Menthol is one of the most important flavouring additives besides vanilla and citrus. The demand for menthol is high and it was previously estimated that the worldwide use of menthol was 30 - 32,000 metric tonnes per annum [12]. Most of the investigations have shown that the major constituents of essential oils in M. piperita were menthol and menthone [7, 9, 10]. The quality of medicinal plants used for the production of pharmacologically useful compounds is usually assessed by the content of biologically active compounds [13]. Several methods such as using of biotic or abiotic elicitor can be a suitable way to increase the production of valuable secondary metabolites in medicinal plants [14], which is currently being implemented extensively owing to its low cost and simplicity of usage [15]. Elicitation is the process of inducing or enhancing synthesis of secondary metabolites by the plants to ensure their survival, persistence and competitiveness [16]. Salicylic acid is a hormone-like substance that plays an important role in the regulation of plant growth and development [7, 17]. In several studies, the effect of salicylic acid on production of many bioactive compounds in medicinal plants was confirmed [13, 18-20]. Yeast extract is one of the biotic elicitors that can result in the improvement of secondary metabolites content. The stimulating influence of yeast extract on secondary metabolites was confirmed in several studies [20-22]. Therefore, in order to economically produce secondary metabolites, it is necessary to use elicitors optimally in medicinal plants. Because of the industrial use of $M$. piperita, it is important to develop an optimal method to obtain standardized plant material with specific quality parameters. Thus, the choice of proper concentration of salicylic acid or yeast extract foliar application can be a suitable strategy to increase the production of the main constituents of $M$. piperita essential oil. Due to the importance of these medicinal compounds, peppermint was therefore studied and explained and the correlation of these compounds was determined.

\section{Materials and Methods}

\subsection{Experimental field}

The experiment was conducted under greenhouse conditions from March to July 2017 at the greenhouse of the Malayer Greenhouse Town, Malayer Municipality (latitude: $34^{\circ} 19^{\prime}$ $\mathrm{N}$, longitude: $48^{\circ} 51^{\prime} \mathrm{E}$, altitude: $1725 \mathrm{~m}$ above sea level), located in the west of Iran and southeast of Hamadan province. 


\subsection{Plant materials, experimental set up and treatments}

In this study, the plant rhizome (Code number: 13723) was obtained from Pakanbazr Company (Isfahan, Iran) (http://www.pakanbazr.com/). For cultivation, 54 clay pots with a height of 25 $\mathrm{cm}$ in diameter (radius) of $20 \mathrm{~cm}$ were used. All pots were containing a 1:1:1 uniform mixture of field soil, rotten leaf soil and sand. Three rhizomes of peppermint with 3 to $5 \mathrm{~cm}$ long were planted in each clay pot in depth of 3 to $5 \mathrm{~cm}$ and a thin layer of rotten manure was poured on them and irrigation was carried out immediately. Plants were grown in a naturally-lit greenhouse where relative humidity ranged of 50-55 \% and average temperature was $25 \pm 3^{\circ} \mathrm{C}$ during the experimental period. During the experimental period, plants were irrigated two to three times a week as required.

\subsection{Experimental design and treatments}

In this study, a completely randomized design experiment with nine treatments and three replications (two pots in each replication) was carried out under greenhouse conditions to investigate the effect of four salicylic acid doses (40, 80, 160 and $320 \mathrm{mg} / \mathrm{l})$, four yeast extract doses $(0.25,0.75,1$ and $1.5 \mathrm{~g} / \mathrm{l})$ and distilled water (control) on major components of peppermint essential oil. For this purpose, yeast extract was dissolved in distilled water. Stock solution of salicylic acid was made by dissolving weighed quantity in minimum quantity of ethanol and final volume made by distilled water. Foliar application of the elicitors on $M$. piperita aerial parts was performed at $40 \%$ flowering stage. In this experiment, distilled water foliar application was used as control. For each treatment, six pots having 3 plants per pot was used. Foliar sprays of the elicitors were done with a portable sprayer, early in the morning and one hour after sunrise. Spraying was done completely on aerial parts of the plants [19]. To evaluate the essential oil composition of $M$. piperita, the sampling was performed 5 days after the foliar application of the elicitors. The samples were dried in the shadow with proper ventilation and normal room temperature $\left(25-30{ }^{\circ} \mathrm{C}\right)$ for 5 days. Each sample was placed in a plastic bag separately and their lids were closed. The characteristics such as amount of essential oil components were measured using gas chromatography-mass spectrometry (GC-MS).

\subsection{Essential oil isolation and analysis procedure}

Essential oil of each sample was isolated from chopped, dried aerial parts of $M$. piperita by hydro-distillation procedure. Briefly, $50 \mathrm{~g}$ of $M$. piperita was transferred into a $1 \mathrm{~L}$ roundbottom flask with Clevenger apparatus. Water distillation was performed for $3 \mathrm{~h}$ at $100{ }^{\circ} \mathrm{C}$. The collected essential oil was dried over anhydrous $\mathrm{Na}_{2} \mathrm{SO}_{4}$ and stored in a dark bottle at $4{ }^{\circ} \mathrm{C}$ until tested and analyzed. The essential oil components of $M$. piperita affected by salicylic acid and yeast extract were determined by gas chromatography-mass spectrometry (GC-MS) using a Hewlett -Packard 5890 gas chromatograph equipped with a flame ionization detector (HP-5970 mass-selective detector-USA) and a $50 \mathrm{~m} \times 0.20 \mathrm{~mm}$ HP-5 (cross-linked Phenyl-Methyl Silicon) column with a $0.25 \mu \mathrm{m}$ film thickness. The ionization energy of the sample components was set to $70 \mathrm{eV}$. The flame ionization detector (FID) was maintained at $250{ }^{\circ} \mathrm{C}$. The temperature program was ranged over $100-250{ }^{\circ} \mathrm{C}$ at a rate of $4{ }^{\circ} \mathrm{C} / \mathrm{min}$. The carrier gas was helium while the flow through the column and the split ratio were set to $1 \mathrm{ml} / \mathrm{min}$ and 100:1, respectively. The individual constituents were identified by their identical 
retention index and compared to those in reference books and articles using mass spectra of standard compounds and information contained in a computer library [23].

\subsection{Statistical analysis}

Data was statistically analyzed by one-way analysis of variance (ANOVA) using SPSS software version 16.0 (SPSS, Inc., Chicago, IL, USA). The mean values were compared using Duncan's multiple range test at $\mathrm{P}<0.01$ significant level. The values are presented as mean \pm standard error (SE) of three replications. Correlation coefficient ( $r$ ) between essential oil components was estimated by Pearson method.

\section{Results}

Essential oil of $M$. piperita aerial parts, were analyzed and quantified by gas chromatographymass spectrometry (GC-MS) (Fig. 1). The effects of salicylic acid and yeast extract foliar application on essential oil components of the plant aerial parts were shown in Tables $1 \& 2$. Results of GC-MS indicated that a total of 40 compounds were identified in the essential oil from the aerial parts of peppermint under salicylic acid and yeast extract treatments. The chemical components are given in Table 2. The results showed that the major components of peppermint essential oil were menthone, menthol, piperitone, isopulegol and $\gamma$-terpinene, respectively (Totally $44.8 \%$ to $54.3 \%$ ). In this study, menthone and menthol were $16.69 \%$ and $14.39 \%$ of the essential oils, respectively. The results of analysis of variance (ANOVA) showed that the effect of different concentrations of salicylic acid and different concentrations of yeast extract on production of 12 major compounds including menthone, neomenthol, isomenthol acetate, piperitone, isopulegol, $\gamma$ terpinene, $\beta$-pinene, myrcene, eucalyptol, dihydrocarvone, paramentol, hexyl isovalerate, caryophyllene oxide was highly significant at 1 $\%$ probability level $(\mathrm{P}<0.01)$, two constituents including $\beta$-ocimene and dihydro carvyl acetate was significant at $5 \%$ probability level $(\mathrm{P}<0.05)$ (Table 1) and on 26 compounds (camphene, sabinene, $\beta$-pinene, $\quad(-)-\beta$-pinene, octenol, $\alpha$-phellandrene, $\alpha$-terpinene, $\quad$ isoterpinolene, p-cymene, limonene, 1,8-cineole, linalool, $\beta$-terpineol, isomenthone, menthofuran, lavandulol, 1-(+)-menthol, myrtenal, $p$-mentenol, carvone, borneol, dihydro carvyl actate, $\beta$ bourbonene, spathulenol, $\beta$-elmene, humulene epoxide) was not significant at $5 \%$ probability level ( $\mathrm{P}>0.05)$ in $M$. piperita (Data not shown). As shown, salicylic acid and yeast extract significantly altered the amount of 14 constituents of essential oil of M. piperita (Table 1). Mean comparison for effects of salicylic acid and yeast extract on essential oil components (\%) in M. piperita is shown in Table 2. The results of mean comparison showed that the amount of menthone varied from $12.13 \%$ to $17.20 \%$. The highest menthone production $17.20 \%$ was obtained at $320 \mathrm{mg} / \mathrm{l}$ salicylic acid treated plants which was $42 \%$ higher compared to control. This was followed by $160 \mathrm{mg} / \mathrm{l}$ salicylic acid (15.97 $\%)$ treatment. The lowest level of menthone production was observed in control $(12.13 \%)$. Also, the results showed that with increasing the amount of yeast extract from 0.75 to $1.5 \mathrm{~g} / \mathrm{l}$, the amount of menthone increased. It is observed that with increasing the amount of salicylic acid from 160 to $320 \mathrm{mg} / \mathrm{l}$, the amount of menthone has increased from 15.97 to $17.20 \%$ (Table 2). The highest neomenthol content $(4.9 \%)$ was approximately $60 \%$ greater than control level, and was obtained in the plants treated with 320 $\mathrm{mg} / \mathrm{l}$ salicylic acid. This was followed by 160 $\mathrm{mg} / \mathrm{l}$ salicylic acid (4.6\%). The lowest level of neomenthol content $(3.08 \%)$ was observed in 
control plants. The results showed that with increasing the concentration of salicylic acid from 40 to $320 \mathrm{mg} / \mathrm{l}$, the amount of neomenthol increased (3.7, 4.2, 4.6 and $4.9 \%$, respectively). In other words, with increasing salicylic acid concentration, the amount of neomenthol has increased. The results of mean comparison showed that with increasing the amount of yeast extract from 0.25 to $1.5 \mathrm{~g} / \mathrm{l}$, the amount of neomenthol increased from 3.20 to $3.93 \%$. The results of mean comparison showed that the amount of piperitone varied from 6.40 to $8.90 \%$. The highest piperitone production $(8.90 \%)$ was obtained at $320 \mathrm{mg} / \mathrm{l}$ salicylic acid treated plants that was $39 \%$ higher compared to control ( 6.40 $\%)$. This was followed by $160 \mathrm{mg} / \mathrm{l}$ salicylic acid $(8.30 \%)$. The effect of different concentrations of yeast extract on the amount of piperitone was not significant compared to the control. The results showed that with elicitation by $320 \mathrm{mg} / \mathrm{l}$ salicylic acid the accumulation of isopulegol was $27 \%$ fewer than the control plants. The lowest amount of isopulegol production $(5.1 \%)$ was obtained at $320 \mathrm{mg} / \mathrm{l}$ salicylic acid treated plants and then the treatment of salicylic acid with a concentration of $160 \mathrm{mg} / \mathrm{l}$ was $5.4 \%$ of essential oil. It is observed that with increasing salicylic acid concentration, the amount of isopulegol has a decreasing trend. Four levels of yeast extract did not have a significant effect on the production of isopulegol in peppermint in greenhouse conditions, but treatments of 80,160 and $320 \mathrm{~g} / \mathrm{l}$ salicylic acid reduced the amount of isopulegol. As shown, the highest $\gamma$-terpinene content (6\% of essential oil) was obtained at $320 \mathrm{mg} / \mathrm{l}$ salicylic acid treated plants which was $59 \%$ higher compared to control. This was followed by $\quad 160 \quad \mathrm{mg} / \mathrm{l} \quad$ and $80 \mathrm{mg} / \mathrm{l}$ salicylic acid (5.63 and $5.27 \%$, respectively). These amounts, considering the amount of $\gamma$-terpinene in the control plants
(3.77\%), could be considered as significant. It is observed that external application of salicylic acid has a positive effect on the production of $\gamma$-terpinene peppermint essential oil compared to yeast extract. Low concentrations of yeast extract are not significantly different from the control. It is observed that only $1.5 \mathrm{~g} / \mathrm{l}$ of yeast extract has significantly different from control. The results of mean comparison for effects of salicylic acid and yeast extract on essential oil components (\%) in M. piperita showed that the highest isomenthol acetate production $7.30 \%$ was obtained at $40 \mathrm{mg} / \mathrm{l}$ salicylic acid treated plants that was 34 $\%$ higher compared to control $(5.43 \%)$. The results showed that with increasing the concentration of yeast extract, the percentage of isomenthol acetate increased and in contrast, with increasing the concentration of salicylic acid from 40 to $320 \mathrm{mg} / \mathrm{l}$, it was observed that the amount of this essential oil compound decreased. Isomenthol acetate content increased significantly only with $40 \mathrm{mg} / \mathrm{l}$ salicylic acid application $(\mathrm{P}<0.01)$.

Pearson correlation coefficient was performed by SPSS software to calculate the relationship between the major constituents of peppermint essential oil (Table 3). In the present study, it was found that salicylic acid and yeast extract, while affecting the amount of some of the major constituents of peppermint essential oil, led to a significant reduction in a number of essential oil constituents. The most significant negative correlation coefficients between isopulegol composition and other major essential oil constituents were neomenthol $\left(\mathrm{r}=-0.886^{* *}\right)$, $\gamma$-terpinene $\left(\mathrm{r}=-0.879^{* *}\right)$, menthone $\left(\mathrm{r}=-0.813^{* *}\right)$ and piperitone $\left(\mathrm{r}=-0.712^{* *}\right)$. In other words, as the amount of major components of the essential oil increased, the amount of isopulegol had an inverse correlation and decreased. The results showed that the menthone content had a 
significant positive correlation with $\gamma$-terpinene ( $\mathrm{r}=0.881^{* *}$, at $\mathrm{P}<0.01$ significant level) and had a significant negative correlation with isopulegol, $\beta$-pinene, myrcene, eucalyptol and $\beta$-ocimene. The results of correlation between essential oil constituents showed that the neomenthol content had a significant positive correlation with menthone $\left(\mathrm{r}=0.865^{* *}\right.$, at $\mathrm{P}<0.01$ significant level), $\gamma$-terpinene $\left(\mathrm{r}=0.848^{* *}\right)$ and had a significant negative correlation with the compounds isopulegol, menthofuran, eucalyptol and $\beta$-ocimene; So that it had a negative correlation with isopulegol $\left(\mathrm{r}=-0.886^{* *}\right)$. The results showed that the $\gamma$-terpinene content had a significant positive correlation with menthone $\left(\mathrm{r}=0.881^{* *}\right.$, at $\mathrm{P}<0.01$ significant level $)$, neomenthol $\left(\mathrm{r}=0.848^{* *}\right)$, piperitone $\left(\mathrm{r}=0.713^{* *}\right)$ and hexyl isovalerate $\left(\mathrm{r}=0.613^{* *}\right)$ and had a significant negative correlation with isopulegol $\left(\mathrm{r}=-0.879^{* *}\right)$. In this study, the major components of peppermint essential oil often had a positive and significant relationship with each other.

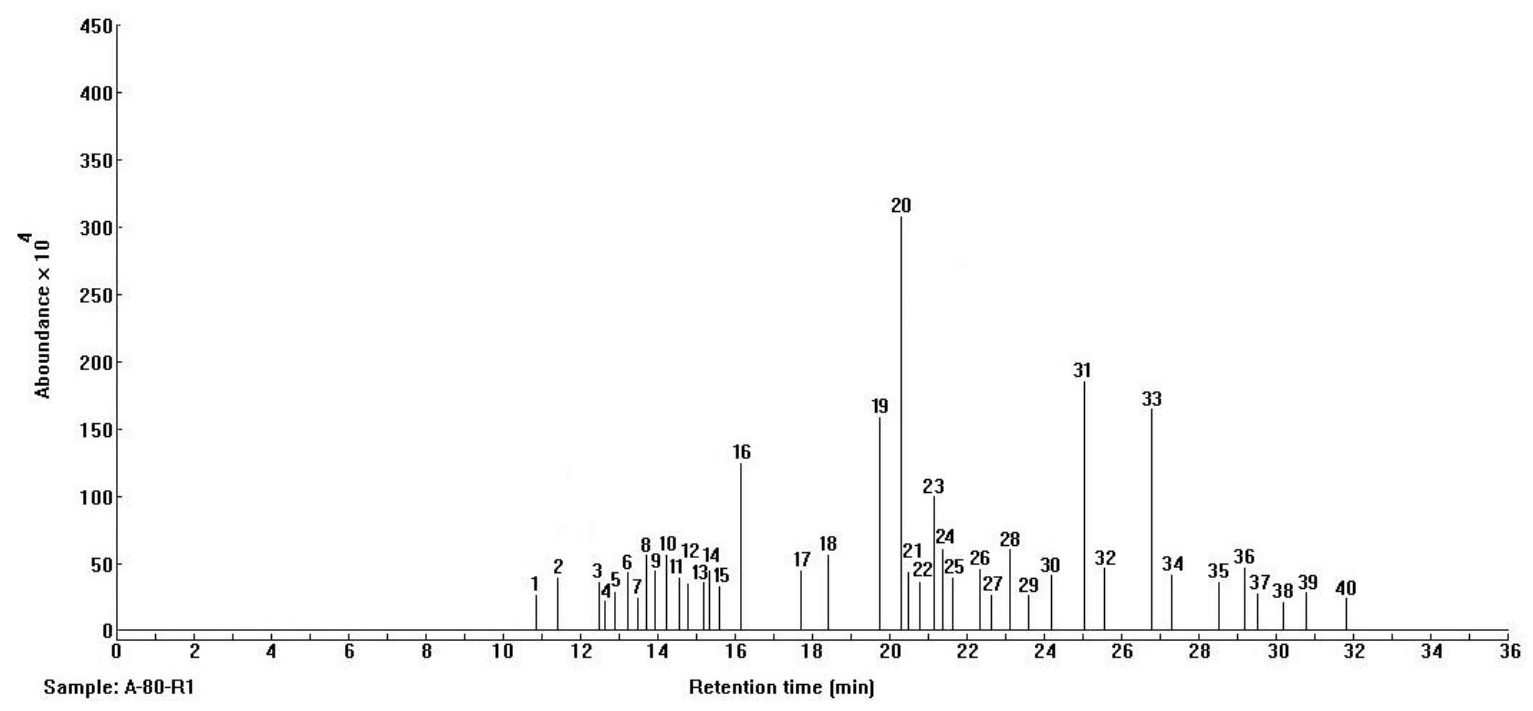

Fig. 1. GC-MS chromatogram of $M$. piperita essential oil treated with $80 \mathrm{mg} / \mathrm{l}$ salicylic acid foliar application (horizontal axis is the time diagram and vertical axis is the frequency)

Table 1. Analysis of variance for the effect of salicylic acid and yeast extract foliar application on essential oil components (\%) in M. piperita

\begin{tabular}{|c|c|c|c|c|c|c|c|c|}
\hline \multirow[b]{2}{*}{$\begin{array}{c}\text { Source of } \\
\text { variation } \\
\text { (S.O.V) }\end{array}$} & \multirow[b]{2}{*}{ df } & \multicolumn{7}{|c|}{ Mean of Squares } \\
\hline & & $\beta$-Pinene & Myrcene & Eucalyptol & $\gamma$-Terpinene & Isopulegol & Menthone & Neomenthol \\
\hline Treatment & 8 & $0.148^{* *}$ & $0.213^{* *}$ & $0.328^{* * *}$ & $1.695^{\text {*** }}$ & $2.012^{* *}$ & $7.302^{* *}$ & $1.169^{\text {*** }}$ \\
\hline Error & 18 & 0.036 & 0.023 & 0.055 & 0.098 & 0.122 & 0.262 & 0.067 \\
\hline Total & 26 & & & & & & & \\
\hline C.V. $(\%)$ & & 16.47 & 14.42 & 19.12 & 6.75 & 5.45 & 3.48 & 6.73 \\
\hline $\begin{array}{c}\text { Source of } \\
\text { variation } \\
\text { (S.O.V) } \\
\end{array}$ & df & Dihydrocarvone & $\begin{array}{c}\text { Hexyl } \\
\text { isovalerate }\end{array}$ & Piperitone & $\begin{array}{l}\text { Isomenthol } \\
\text { acetate }\end{array}$ & $\begin{array}{l}\text { Caryophyllene } \\
\text { oxide }\end{array}$ & $\beta$-Ocimene & $\begin{array}{l}\text { Dihydrocarvyl } \\
\text { actate }\end{array}$ \\
\hline Treatment & 8 & $0.162^{* *}$ & $0.519^{* *}$ & $2.097^{* *}$ & $1.251^{* * *}$ & $0.141^{* *}$ & $0.227^{*}$ & $0.101^{*}$ \\
\hline Error & 18 & 0.029 & 0.024 & 0.250 & 0.129 & 0.034 & 0.063 & 0.031 \\
\hline Total & 26 & & & & & & & \\
\hline C.V. $(\%)$ & & 9.62 & 22.85 & 6.90 & 19.99 & 13.64 & 22.17 & 18.08 \\
\hline
\end{tabular}

*, ** Significantly different at the 5 and $1 \%$ probability level, respectively 
Table 2. Mean comparison for effects of salicylic acid and yeast extract on essential oil components (\%) in M. piperita

\begin{tabular}{|c|c|c|c|c|c|c|c|c|c|c|}
\hline \multirow{2}{*}{ Compounds (\%) } & \multirow{2}{*}{$\begin{array}{c}\text { RT } \\
(\mathbf{m i n})\end{array}$} & \multicolumn{9}{|c|}{ Treatment } \\
\hline & & Control & YE-0.25 & YE-0.75 & YE-1 & YE-1.5 & SA-40 & SA-80 & SA-160 & SA-320 \\
\hline$\alpha$-Pinene & 10.87 & $1.40^{\mathrm{a}}$ & $1.20^{\mathrm{a}}$ & $1.27^{\mathrm{a}}$ & $1.07^{\mathrm{a}}$ & $1.20^{\mathrm{a}}$ & $1.13^{\mathrm{a}}$ & $0.97^{\mathrm{a}}$ & $0.97^{\mathrm{a}}$ & $1.10^{\mathrm{a}}$ \\
\hline Camphene & 11.33 & $1.83^{\mathrm{a}}$ & $1.70^{\mathrm{a}}$ & $1.63^{\mathrm{a}}$ & $1.60^{\mathrm{a}}$ & $1.77^{\mathrm{a}}$ & $1.63^{\mathrm{a}}$ & $1.63^{\mathrm{a}}$ & $1.57^{\mathrm{a}}$ & $1.50^{\mathrm{a}}$ \\
\hline Sabinene & 12.43 & $2.10^{\mathrm{a}}$ & $1.73^{\mathrm{a}}$ & $1.77^{\mathrm{a}}$ & $1.83^{\mathrm{a}}$ & $1.63^{\mathrm{a}}$ & $1.83^{\mathrm{a}}$ & $1.77^{\mathrm{a}}$ & $1.73^{\mathrm{a}}$ & $1.67^{\mathrm{a}}$ \\
\hline$\beta$-Pinene & 12.64 & $1.63^{\mathrm{a}}$ & $1.30^{\mathrm{ab}}$ & $1.03^{\mathrm{b}}$ & $1.00^{\mathrm{b}}$ & $1.13^{\mathrm{b}}$ & $1.23^{\mathrm{ab}}$ & $1.03^{b}$ & $1.13^{\mathrm{b}}$ & $0.87^{\mathrm{b}}$ \\
\hline (-)- $\beta$-Pinene & 12.96 & $1.73^{\mathrm{a}}$ & $1.83^{\mathrm{a}}$ & $1.47^{\mathrm{a}}$ & $1.33^{\mathrm{a}}$ & $1.63^{\mathrm{a}}$ & $1.63^{\mathrm{a}}$ & $1.47^{\mathrm{a}}$ & $1.37^{\mathrm{a}}$ & $1.43^{\mathrm{a}}$ \\
\hline Octenol & 13.27 & $2.13^{\mathrm{a}}$ & $1.80^{\mathrm{a}}$ & $1.87^{\mathrm{a}}$ & $1.60^{\mathrm{a}}$ & $1.67^{\mathrm{a}}$ & $1.50^{\mathrm{a}}$ & $1.80^{\mathrm{a}}$ & $1.67^{\mathrm{a}}$ & $1.67^{\mathrm{a}}$ \\
\hline Myrcene & 13.50 & $1.43^{\mathrm{a}}$ & $1.57^{\mathrm{a}}$ & $1.07^{\mathrm{b}}$ & $0.90^{\mathrm{b}}$ & $0.97^{\mathrm{b}}$ & $0.80^{\mathrm{b}}$ & $0.90^{\mathrm{b}}$ & $0.97^{\mathrm{b}}$ & $0.87^{\mathrm{b}}$ \\
\hline$\alpha$-Phellandrene & 13.76 & $2.47^{\mathrm{a}}$ & $2.57^{\mathrm{a}}$ & $2.30^{\mathrm{a}}$ & $2.77^{\mathrm{a}}$ & $2.87^{\mathrm{a}}$ & $2.63^{\mathrm{a}}$ & $2.30^{\mathrm{a}}$ & $2.43^{\mathrm{a}}$ & $2.37^{\mathrm{a}}$ \\
\hline$\alpha$-Terpinene & 13.95 & $1.83^{\mathrm{a}}$ & $1.93^{\mathrm{a}}$ & $1.93^{\mathrm{a}}$ & $1.90^{\mathrm{a}}$ & $1.60^{\mathrm{a}}$ & $1.43^{\mathrm{a}}$ & $1.93^{\mathrm{a}}$ & $1.63^{\mathrm{a}}$ & $1.57^{\mathrm{a}}$ \\
\hline Isoterpinolene & 14.26 & $2.27^{\mathrm{a}}$ & $2.20^{\mathrm{a}}$ & $2.07^{\mathrm{a}}$ & $1.90^{\mathrm{a}}$ & $2.10^{\mathrm{a}}$ & $2.17^{\mathrm{a}}$ & $2.10^{\mathrm{a}}$ & $2.03^{\mathrm{a}}$ & $2.03^{\mathrm{a}}$ \\
\hline$p$-Cymene & 14.69 & $1.90^{\mathrm{a}}$ & $2.07^{\mathrm{a}}$ & $1.80^{\mathrm{a}}$ & $1.67^{\mathrm{a}}$ & $1.57^{\mathrm{a}}$ & $1.70^{\mathrm{a}}$ & $1.63^{\mathrm{a}}$ & $2.07^{\mathrm{a}}$ & $1.37^{\mathrm{a}}$ \\
\hline Eucalyptol & 14.88 & $1.90^{\mathrm{a}}$ & $1.57^{\mathrm{ab}}$ & $0.90^{c}$ & $1.20^{\mathrm{bc}}$ & $1.20^{\mathrm{bc}}$ & $1.17^{\mathrm{bc}}$ & $1.17^{\mathrm{bc}}$ & $1.13^{\mathrm{bc}}$ & $0.80^{c}$ \\
\hline Limonene & 15.16 & $2.03^{\mathrm{a}}$ & $1.90^{\mathrm{a}}$ & $2.07^{\mathrm{a}}$ & $1.97^{\mathrm{a}}$ & $1.73^{\mathrm{a}}$ & $1.83^{\mathrm{a}}$ & $1.73^{\mathrm{a}}$ & $1.60^{\mathrm{a}}$ & $1.53^{\mathrm{a}}$ \\
\hline 1,8-Cineole & 15.30 & $2.03^{\mathrm{a}}$ & $2.00^{\mathrm{a}}$ & $1.97^{\mathrm{a}}$ & $1.93^{\mathrm{a}}$ & $2.00^{\mathrm{a}}$ & $1.90^{\mathrm{a}}$ & $1.90^{\mathrm{a}}$ & $1.90^{\mathrm{a}}$ & $1.90^{\mathrm{a}}$ \\
\hline$\beta$-Ocimene & 15.66 & $1.57^{\mathrm{a}}$ & $1.47^{\mathrm{a}}$ & $1.30^{\mathrm{ab}}$ & $1.10^{\mathrm{abc}}$ & $0.80^{c}$ & $1.17^{\mathrm{abc}}$ & $1.10^{\mathrm{abc}}$ & $0.80^{c}$ & $0.90^{\mathrm{bc}}$ \\
\hline$\gamma$-Terpinene & 16.19 & $3.77^{\mathrm{f}}$ & $4.03^{\mathrm{ef}}$ & $4.23^{\mathrm{def}}$ & $4.37^{\text {def }}$ & $4.70^{\text {cde }}$ & $4.87^{\text {bcd }}$ & $5.27^{\mathrm{abc}}$ & $5.63^{\mathrm{ab}}$ & $6.00^{a}$ \\
\hline Linalool & 17.78 & $2.00^{\mathrm{a}}$ & $1.90^{\mathrm{a}}$ & $1.90^{\mathrm{a}}$ & $1.90^{\mathrm{a}}$ & $1.70^{\mathrm{a}}$ & $1.97^{\mathrm{a}}$ & $1.77^{\mathrm{a}}$ & $1.87^{\mathrm{a}}$ & $1.80^{\mathrm{a}}$ \\
\hline$\beta$-Terpineol & 18.38 & $1.93^{\mathrm{a}}$ & $1.80^{\mathrm{a}}$ & $2.17^{\mathrm{a}}$ & $2.00^{\mathrm{a}}$ & $1.87^{\mathrm{a}}$ & $1.67^{\mathrm{a}}$ & $2.10^{\mathrm{a}}$ & $1.80^{\mathrm{a}}$ & $1.63^{\mathrm{a}}$ \\
\hline Isopulegol & 19.81 & $7.00^{\mathrm{ab}}$ & $7.63^{a}$ & $7.10^{\mathrm{ab}}$ & $6.77^{\text {abc }}$ & $6.40^{\mathrm{bc}}$ & $6.30^{b c}$ & $6.00^{\text {cd }}$ & $5.40^{\mathrm{de}}$ & $5.10^{e}$ \\
\hline Menthone & 20.18 & $12.13^{\mathrm{f}}$ & $13.03^{\text {ef }}$ & $13.83^{\text {de }}$ & $14.57^{\mathrm{cd}}$ & $15.70^{b c}$ & $14.70^{\text {bcd }}$ & $15.40^{\mathrm{bc}}$ & $15.97^{\mathrm{b}}$ & $17.20^{\mathrm{a}}$ \\
\hline Isomenthone & 20.50 & $2.10^{\mathrm{a}}$ & $1.90^{\mathrm{a}}$ & $1.93^{\mathrm{a}}$ & $2.10^{\mathrm{a}}$ & $1.73^{\mathrm{a}}$ & $2.10^{\mathrm{a}}$ & $1.93^{\mathrm{a}}$ & $1.90^{\mathrm{a}}$ & $1.97^{\mathrm{a}}$ \\
\hline Menthofuran & 20.86 & $2.00^{\mathrm{a}}$ & $1.90^{\mathrm{a}}$ & $2.07^{\mathrm{a}}$ & $1.90^{\mathrm{a}}$ & $1.83^{\mathrm{a}}$ & $1.77^{\mathrm{a}}$ & $1.70^{\mathrm{a}}$ & $1.93^{\mathrm{a}}$ & $1.33^{\mathrm{a}}$ \\
\hline Neomenthol & 21.11 & $3.07^{\mathrm{e}}$ & $3.20^{\mathrm{e}}$ & $3.40^{\mathrm{de}}$ & $3.60^{\text {cde }}$ & $3.93^{\mathrm{cd}}$ & $3.70^{\text {cde }}$ & $4.20^{\mathrm{bc}}$ & $4.60^{\mathrm{ab}}$ & $4.90^{\mathrm{a}}$ \\
\hline Lavandulol & 21.40 & $2.30^{\mathrm{a}}$ & $2.53^{\mathrm{a}}$ & $2.70^{\mathrm{a}}$ & $2.53^{\mathrm{a}}$ & $2.53^{\mathrm{a}}$ & $2.30^{\mathrm{a}}$ & $2.53^{\mathrm{a}}$ & $2.53^{\mathrm{a}}$ & $2.40^{\mathrm{a}}$ \\
\hline l-(+)-Menthol & 21.73 & $1.97^{\mathrm{a}}$ & $1.87^{\mathrm{a}}$ & $1.73^{\mathrm{a}}$ & $1.87^{\mathrm{a}}$ & $1.67^{\mathrm{a}}$ & $1.77^{\mathrm{a}}$ & $1.80^{\mathrm{a}}$ & $1.67^{\mathrm{a}}$ & $1.83^{\mathrm{a}}$ \\
\hline Myrtenal & 22.31 & $2.070^{\mathrm{a}}$ & $1.80^{\mathrm{a}}$ & $2.00^{\mathrm{a}}$ & $1.93^{\mathrm{a}}$ & $1.70^{\mathrm{a}}$ & $1.87^{\mathrm{a}}$ & $1.87^{\mathrm{a}}$ & $1.73^{\mathrm{a}}$ & $1.77^{\mathrm{a}}$ \\
\hline Dihydrocarvone & 22.66 & $1.13^{\mathrm{b}}$ & $1.70^{\mathrm{a}}$ & $1.17^{\mathrm{b}}$ & $1.00^{\mathrm{b}}$ & $1.10^{\mathrm{b}}$ & $0.93^{\mathrm{b}}$ & $1.03^{b}$ & $1.10^{\mathrm{b}}$ & $0.93^{\mathrm{b}}$ \\
\hline$p$-Mentenol & 23.08 & $2.90^{\mathrm{a}}$ & $2.40^{\mathrm{a}}$ & $2.63^{\mathrm{a}}$ & $2.87^{\mathrm{a}}$ & $2.83^{\mathrm{a}}$ & $3.00^{\mathrm{a}}$ & $2.67^{\mathrm{a}}$ & $2.57^{\mathrm{a}}$ & $2.87^{\mathrm{a}}$ \\
\hline Hexyl isovalerate & 23.60 & $0.00^{\mathrm{c}}$ & $0.00^{\mathrm{c}}$ & $0.70^{\mathrm{ab}}$ & $1.03^{\mathrm{a}}$ & $0.57^{\mathrm{b}}$ & $1.00^{\mathrm{a}}$ & $1.00^{\mathrm{a}}$ & $0.80^{\mathrm{ab}}$ & $1.00^{\mathrm{a}}$ \\
\hline Carvone & 24.11 & $1.83^{\mathrm{a}}$ & $1.93^{\mathrm{a}}$ & $1.83^{\mathrm{a}}$ & $1.90^{\mathrm{a}}$ & $1.93^{\mathrm{a}}$ & $1.80^{\mathrm{a}}$ & $1.90^{\mathrm{a}}$ & $1.87^{\mathrm{a}}$ & $1.90^{\mathrm{a}}$ \\
\hline Piperitone & 25.05 & $6.40^{c}$ & $6.60^{c}$ & $6.87^{\mathrm{c}}$ & $6.80^{c}$ & $7.50^{\mathrm{bc}}$ & $6.87^{\mathrm{c}}$ & $7.00^{c}$ & $8.30^{\mathrm{ab}}$ & $8.90^{\mathrm{a}}$ \\
\hline Borneol & 25.60 & $1.93^{\mathrm{a}}$ & $1.87^{\mathrm{a}}$ & $1.83^{\mathrm{a}}$ & $1.80^{\mathrm{a}}$ & $1.73^{\mathrm{a}}$ & $1.67^{\mathrm{a}}$ & $1.73^{\mathrm{a}}$ & $1.73^{\mathrm{a}}$ & $1.60^{\mathrm{a}}$ \\
\hline Isomenthol acetate & 26.81 & $5.43^{\mathrm{de}}$ & $5.23^{\mathrm{e}}$ & $5.73^{\text {bcde }}$ & $6.20^{\mathrm{bcd}}$ & $6.40^{\mathrm{bc}}$ & $7.30^{\mathrm{a}}$ & $6.43^{b}$ & $5.83^{\text {bcde }}$ & $5.50^{\text {cde }}$ \\
\hline Dihydro carvyl actate & 27.21 & $1.93^{\mathrm{abc}}$ & $1.73^{\text {bcd }}$ & $2.07^{\mathrm{a}}$ & $2.00^{\mathrm{ab}}$ & $1.67^{\mathrm{bcd}}$ & $1.63^{\text {cd }}$ & $1.67^{\mathrm{bcd}}$ & $1.70^{\mathrm{bcd}}$ & $1.53^{\mathrm{d}}$ \\
\hline$\beta$-Bourbonene & 28.52 & $1.90^{\mathrm{a}}$ & $1.83^{\mathrm{a}}$ & $1.77^{\mathrm{a}}$ & $1.73^{\mathrm{a}}$ & $1.83^{\mathrm{a}}$ & $1.73^{\mathrm{a}}$ & $1.40^{\mathrm{a}}$ & $1.33^{\mathrm{a}}$ & $1.47^{\mathrm{a}}$ \\
\hline Spathulenol & 29.14 & $1.77^{\mathrm{a}}$ & $1.63^{\mathrm{a}}$ & $2.00^{\mathrm{a}}$ & $1.90^{\mathrm{a}}$ & $1.70^{\mathrm{a}}$ & $1.60^{\mathrm{a}}$ & $2.00^{\mathrm{a}}$ & $1.70^{\mathrm{a}}$ & $1.77^{\mathrm{a}}$ \\
\hline$\beta$-Elmene & 29.52 & $0.97^{\mathrm{a}}$ & $1.10^{\mathrm{a}}$ & $1.33^{\mathrm{a}}$ & $1.13^{\mathrm{a}}$ & $0.90^{\mathrm{a}}$ & $0.77^{\mathrm{a}}$ & $0.87^{\mathrm{a}}$ & $0.90^{\mathrm{a}}$ & $0.87^{\mathrm{a}}$ \\
\hline Dihydrocarvyl acetate & 30.18 & $1.33^{\mathrm{a}}$ & $1.30^{\mathrm{a}}$ & $0.87^{\mathrm{a}}$ & $0.87^{\mathrm{a}}$ & $0.77^{\mathrm{a}}$ & $1.03^{\mathrm{a}}$ & $1.00^{\mathrm{a}}$ & $0.77^{\mathrm{a}}$ & $0.83^{\mathrm{a}}$ \\
\hline Caryophyllene oxide & 30.86 & $1.63^{\mathrm{a}}$ & $1.63^{\mathrm{a}}$ & $1.27^{\mathrm{ab}}$ & $1.00^{\mathrm{b}}$ & $1.10^{\mathrm{b}}$ & $1.30^{\mathrm{ab}}$ & $1.33^{\mathrm{ab}}$ & $1.47^{\mathrm{ab}}$ & $1.43^{\mathrm{ab}}$ \\
\hline Humulene epoxide & 31.90 & $1.37^{\mathrm{a}}$ & $1.43^{\mathrm{a}}$ & $1.27^{\mathrm{a}}$ & $1.17^{\mathrm{a}}$ & $1.30^{\mathrm{a}}$ & $1.30^{\mathrm{a}}$ & $0.87^{\mathrm{a}}$ & $1.07^{\mathrm{a}}$ & $1.00^{\mathrm{a}}$ \\
\hline
\end{tabular}

Means followed by similar letter (s) in each row are not significantly different by Duncan's multiple range test at $\mathrm{P}<0.01$. The values are mean of three replicates \pm standard error (SE). RT: Retention time (min). YE: Yeast extract (g/l). SA: Salicylic acid (mg/l). 
Table 3. Pearson's correlation coefficients between some essential oil compositions in peppermint under salicylic acid and yeast extract foliar application

\begin{tabular}{|c|c|c|c|c|c|c|c|c|c|c|c|}
\hline 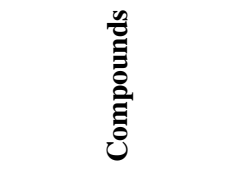 & & 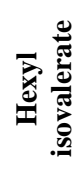 & 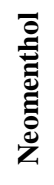 & 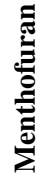 & 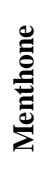 & 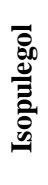 & 苞 & 苞 & 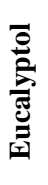 & 芯 & : \\
\hline$\beta$-Pinene & 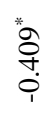 & $\begin{array}{l}\text { 恶 } \\
\hat{a} \\
\dot{0}\end{array}$ & $\frac{.}{\circ}$ & $\begin{array}{l}\stackrel{*}{T} \\
\stackrel{+}{0}\end{array}$ & 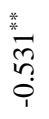 & 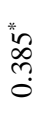 & 贲 & $\begin{array}{l}\text { సิ } \\
\text { லิ }\end{array}$ & 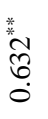 & 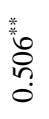 & - \\
\hline Myrcene & 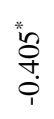 & 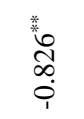 & $\begin{array}{l}\text { 尊 } \\
\text { 它 } \\
\stackrel{0}{0}\end{array}$ & 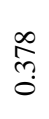 & $\frac{\text { *. }}{\stackrel{2}{\circ}}$ & 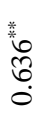 & 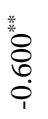 & 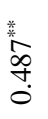 & 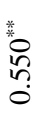 & - & ' \\
\hline Eucalyptol & $\begin{array}{l}\overrightarrow{0} \\
\text { ?} \\
i\end{array}$ & 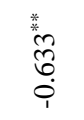 & 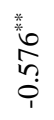 & $\vec{m}$ & 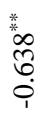 & \begin{tabular}{l} 
*o \\
o \\
\multirow{2}{*}{} \\
0
\end{tabular} & 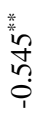 & 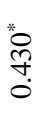 & - & ' & ' \\
\hline$\beta$-Ocimene & $\begin{array}{l}\stackrel{*}{\infty} \\
\stackrel{*}{0} \\
0 \\
0\end{array}$ & 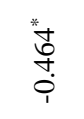 & $\begin{array}{l}* \\
\infty \\
\infty \\
n \\
0 \\
1\end{array}$ & $\begin{array}{l}8 \\
0 \\
0\end{array}$ & 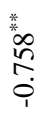 & \begin{tabular}{l} 
*. \\
\multirow{0}{0}{} \\
$n$ \\
0
\end{tabular} & $\begin{array}{l}\stackrel{*}{*} \\
\overline{6} \\
\stackrel{0}{0}\end{array}$ & - & ' & ' & ' \\
\hline$\gamma$-Terpinene & $\frac{\text { : }}{\stackrel{2}{2}}$ & 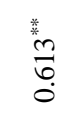 & 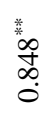 & 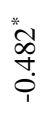 & $\begin{array}{l}* \\
\infty \\
\infty \\
0 \\
0\end{array}$ & 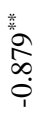 & - & ' & ' & ' & ' \\
\hline Isopulegol & $\underset{i}{\stackrel{*}{*}}$ & 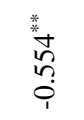 & $\begin{array}{l}\text { *. } \\
\infty \\
\infty \\
\infty \\
0 \\
1\end{array}$ & $\begin{array}{l}\stackrel{*}{2} \\
\stackrel{+}{+} \\
\stackrel{0}{0}\end{array}$ & $\begin{array}{l}\stackrel{*}{m} \\
\stackrel{\infty}{\infty} \\
\dot{0}\end{array}$ & - & ' & ' & ' & ' & \\
\hline Menthone & 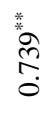 & $\begin{array}{l}\text { \% } \\
\stackrel{*}{\infty} \\
\infty \\
0 \\
0 \\
0\end{array}$ & $\begin{array}{l}\text { wo } \\
\stackrel{0}{0} \\
\infty \\
0\end{array}$ & 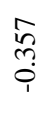 & - & ' & ' & ' & ' & ' & 1 \\
\hline Menthofuran & 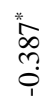 & $\begin{array}{l}\underset{J}{J} \\
\stackrel{+}{0}\end{array}$ & 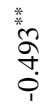 & - & ' & ' & ' & ' & ' & ' & \\
\hline Neomenthol & $\stackrel{\text { Fo }}{\stackrel{+}{+}}$ & 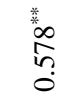 & - & ' & ' & ' & ' & ' & ' & ' & ' \\
\hline Hexyl isovalerate & 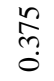 & - & ' & 1 & ' & ' & ' & ' & ' & ' & \\
\hline Piperitone & - & ' & , & ' & ' & , & ' & ' & ' & ' & 1 \\
\hline
\end{tabular}

* ${ }^{* *}$ Significantly different at the 5 and $1 \%$ probability level, respectively

\section{Discussion}

The quality of plants used for production of pharmacological compounds is usually assessed by secondary metabolite content [13]. High- quality oils of $M$. piperita are characterized by a complex compositional balance of monoterpenes with high menthol, moderate menthone, and low pulegone and menthofuran quantities [26]. In this 
study, the identified essential oil compounds of M. piperita aerial parts are listed in Table 2 . Elicitation effects of salicylic acid and yeast extract were investigated and 40 compounds were identified in peppermint essential oil using GC-MS that menthone and menthol were major components (16.69\% and $14.39 \%$ of the essential oils, respectively). To our best knowledge, results are consistent with other studies, wherein menthol and menthone were the most abundant constituents in $M$. piperita essential oils [7-10, 12]. Similarly, it was observed that in the aerial parts of cultivated M. piperita plants, a total of 39 compounds were identified in essential oil by hydro-distillation method. The main components in the hydrodistillation procedure were menthol $(45.34 \%)$, menthone $(16.04 \%)$ and menthofuran $(8.91 \%)$ [9]. It was reported that a total of 28 compounds were identified in the essential oil from peppermint aerial parts under salicylic acid treatments and the major constituents (more than $70 \%)$ were menthol, menthone, and isomenthone, respectively [7]. It was observed that a total of 29 compounds were identified in the essential oil from aerial parts of peppermint and the main constituents in the essential oil were camphane (14.01\%), menthone (13.89\%), menthol (12.37 \%) $\beta$-pinene $(7.62 \%)$ and pulegone $(6.41 \%)$ [8]. The results of an investigation showed that the major components of the oil were menthone, menthol, menthofuran, pulegone, 1,8-cineole, and menthyl acetate [10]. In another experiment, it was found that the major compounds identified were isomenthone (27.4\%), menthol (24.3\%), menthone (9.2\%), limonene $(5.8 \%)$, 1,8-cineole (5.6\%), menthofuran $(4.4 \%)$ and isomenthol $(3.2 \%)$ [12]. In addition, results of an investigation indicated that a total of 33 compounds were detected in the essential oil samples of peppermint treated with different salicylic acid concentrations with menthone (15.8-18.1\%), menthol (46.3-47.4\%), methyl acetate (8.5-9.7\%) and 1,8-cineole (4.3-4.6\%) being the major ones [19]. It is observed that in all researches, menthol and menthone were the main constituents of peppermint essential oil. A comparison of our results with the previous reports suggests some variation in quantities and quality of components within the essential oil of the plants. The phytochemical variability of $M$. piperita oils is may be due to the geographical conditions of the plant sample, agronomic practices, climatic, harvesting time and drying method as well as essential oils extraction procedure [3, 24-25]. The variation in the percentage of some constituents within the essential oil showed trend as a result of the salicylic acid and yeast extract exposure treatment. Our experimental results show that essential oil compounds of $M$. piperita aerial parts can be significantly stimulated by both biotic and abiotic elicitors. Salicylic acid from $40-320 \mathrm{mg} / \mathrm{l}$ and yeast ex tract from 0.25-1.5 $\mathrm{g} / \mathrm{l}$ exhibited different eliciting effects on major components of $M$. piperita. The lowest level of major components production was observed in control plants that distilled water was used for foliar application. In present study, with increasing salicylic acid concentration, the amount of menthone, neomenthol, piperitone, $\gamma$-terpinene have increased. The highest percentage of those components were obtained at $320 \mathrm{mg} / \mathrm{l}$ salicylic acid treated plants that were 42, 60, 39 and $59 \%$ higher compared to control. Several reports have shown that exogenous application of salicylic acid has a positive effects on production of many bioactive compounds in medicinal plants [7, 13, 18, and 19]. Similarly, it was reported that the foliar application by $10 \mathrm{mM}$ of salicylic acid and $1.5 \mathrm{mg} / \mathrm{l}$ indol-3-acetic acid increased major essential oil components of 
M. piperita and Melissa officinalis aerial parts [7]. In another experiment, it was found that foliar treatment of lemon balm plants with salicylic acid considerably enhanced the monoterpene oxygenated and sesquiterpenes secondary metabolites [18]. It was found that the main oil components were not markedly affected by different salicylic acid treatments. However, the maximum concentration of menthol (47.4\%) was observed when $150 \mathrm{mg} / \mathrm{l}$ salicylic acid applied [19] which this is not in agreement with the results obtained in this study. The findings of the present study substantiated the role of salicylic acid as an elicitor that with increasing the amount from 160 to $320 \mathrm{mg} / \mathrm{l}$ the content of main constituents of essential oil in aerial parts of $M$. piperita except isopulegol increased. The results of GC-MS analysis of peppermint aerial parts showed that yeast extract significantly altered the amount of some of the main constituents. In present study, the results showed that with increasing the concentrations of yeast extract from 0.75 to $1.5 \mathrm{~g} / \mathrm{l}$, the amount of menthone, neomenthol and $\gamma$-terpinene increased. Also, four levels of yeast extract did not have a significant effect on the production of piperitone and isopulegol compared to the control. The stimulating influence of yeast extract on secondary metabolites was confirmed in several studies [1, 20-22]. The majority of biotic elicitors are recognized by specific receptors bound to the cell membrane. These stimulants are then transferred to the cell by a signal transduction system, producing changes that ultimately lead to the formation of phytoalexins [27]. In general, it was clearly observed from Table 2 that different types of elicitors exhibited distinct influences on the phytochemical accumulation in $M$. piperita. This indicated that the sensitivity of biologically active compounds biosynthesis toward elicitation varied with the elicitors used in $M$. piperita. In this research, correlation coefficient of essential oils compositions in peppermint under salicylic acid and yeast extract foliar application was calculated. In general, often the major constituents of peppermint essential oil in the conditions of this study had a positive and significant relationship with each other. In another experiment, it was found that most of the major constituents of the essential oil of $M$. piperita and $M$. officinalis both had significant positive correlation with each other [7] which was in agreement with the results of this study.

\section{Conclusion}

In conclusion, the quality of essential oil of $M$. piperita were influenced by the foliar application of salicylic acid and yeast extract at the appropriate concentrations. Forty compounds were identified in peppermint essential oil that the major components were menthone, menthol, piperitone, isopulegol and $\gamma$-terpinene, respectively. Salicylic acid was effective at high concentration $(320 \mathrm{mg} / \mathrm{l})$ for menthone, $\gamma$-terpinene, neomenthol and piperitone production. In this study, the major components of peppermint essential oil had a positive and significant relationship with each other, generally. The results can be useful to apply in modern agriculture for enhancing the quality of peppermint.

\section{Author contributions}

M. M. carried out the experiment and contributed in data gathering. M. A. supervised the research, assisted in data analysis and wrote the manuscript.

\section{Conflict of interest}

The authors declare that there is no conflict of interest. 


\section{References}

1. Deepthi S and Satheeshkumar K. Enhanced camptothecin production induced by elicitors in the cell suspension cultures of Ophiorrhiza mungos Linn. Plant Cell Tissue Organ Cult. 2016; 124: 483-493. doi: 10.1007/s11240-0150908-y.

2. Edris AE. Pharmaceutical and therapeutic potentials of essential oils and their individual volatile constituents: a review. Phytother. Res. 2007; 21 (4): 308-323. doi: 10.1002/ptr.2072.

3. Mahendran $G$ and Rahman LU. Ethnomedicinal, phytochemical and pharmacological updates on peppermint (Mentha piperita L.) A review. Phytother. Res. 2020; 152. doi.org/10.1002/ptr.6664.

4. Rita $P$ and Animesh DK. An updated overview on peppermint (Mentha piperita L.). Int. Res. J. Pharm. 2011; 2: 1-10.

5. Brahmi F, Khodir M, Mohamed C and Pierre D. Chemical Composition and Biological Activities of Mentha species. In: El-Shemy HA. Aromatic and Medicinal Plants - Back to Nature. Rijeka: IntechOpen; 2017: 47-80. doi: 10.5772/ 67291.

6. Sahib N, Anwar F, Gilani AH, Hamid AA, Saari $\mathrm{N}$ and Alkharfy KM. Coriander (Coriandrum sativum L.): a potential source of high-value components for functional foods and nutraceuticals - a review. Phytother. Res. 2013; 27 (10): 1439-1456. doi: 10.1002/ptr.4897.

7. Ahmadi S, Yadegari M and Hamedi B. Foliar application effects of salicylic acid and indole acetic acid on the essential oil composition of Mentha piperita L. and Melissa officinalis L. J. Plant Proc. Func. 2018; 7 (26): 251-262. [In Persian].

8. Golparvar AR and Hadipanah A. Chemical compositions of the essential oil from peppermint (Mentha piperita L.) cultivated in Isfahan conditions. J. Herb. Drug. 2013; 4 (2): 75-80.

Journal of Medicinal Plants
9. Taherpour AA, Khaef S, Yari A, Nikeafshar $S$, Fathi $M$ and Ghambari S. Chemical composition analysis of the essential oil of Mentha piperita L. from Kermanshah, Iran by hydrodistillation and HS/SPME methods. $J$. Anal. Sci. Technol. 2017; 8: 11. doi: 10.1186/s40543-017-0122-0.

10. Soltani F, Sharifi $M$, Khajeh $K$ and Yousefzadi M. Study of essential oil composition, menthone reductase activity and antimicrobial activity of Mentha piperita in two stages of growth. Iranian Journal of Biology 2009; 22 (1): 62-70. [In Persian].

11. Seif Sahandi M, Naghdi-Badi H, Mehrafarin A, Khalighi-Sigaroodi F and Sharifi M. Changes in essential oil content and composition of peppermint (Mentha piperita L.) in responses to nitrogen application. J. Med. Plants 2019; 18 (72): 81-97. doi: 10.29252/jmp.4.72.81. [In Persian].

12. Kamatou GPP, Vermaak I, Viljoen AM and Lawrence BM. Menthol: A simple monoterpene with remarkable biological properties. Phytochemistry 2013; 96: 15-25. doi: 10.1016/j.phytochem.2013.08.005.

13. Kuzel S, Vydra J, Triska J, Vrchotova N, Hruby $M$ and Cigler $P$. Elicitation of pharmacologically active substances in an intact medical plant. J. Agric. Food Chem. 2009; 57: 7907-7911. doi: 10.1021/jf9011246.

14. Abbasi BH, Saxena PK, Murch SJ and Liu CZ. Echinacea biotechnology: challenges and opportunities. In Vitro Cell Dev. Biol.-Plant. 2007; 43: 481-492. doi: 10.1007/s11627-0079057-2.

15. Isah $T$, Umar $S$, Mujib A, Sharma MP, Rajasekharan PE, Zafar $\mathrm{N}$ and Frukh A. Secondary metabolism of pharmaceuticals in the plant in vitro cultures: strategies, approaches, and limitations to achieving higher yield. Plant Cell, Tissue Organ Cult. 2018; 132: 239-265. doi: 10.1007/s11240-017-1332-2. 
16. Gorelick $\mathrm{J}$ and Bernstein N. Chemical and physical elicitation for enhanced cannabinoid production in cannabis (Cannabis sativa L.). Botany and Biotechnology, Chandra S, Lata $\mathrm{H}$ and ElSohly MA. Eds.; Springer International Publishing: Cham. Switzerland, 2017, pp: 439456.

17. Szepesi A, Poor P, Gemes K, Horvath E and Tari I. Influence of exogenous salicylic acid on antioxidant enzyme activities in the roots of salt stressed tomato plants. Acta Biol. Szeged. 2008; 52 (1): 199-200.

18. Ghasemi Pirbalouti A, Nekoei M, Rahimmalek $\mathrm{M}$ and Malekpoor F. Chemical composition and yield of essential oil from lemon balm (Melissa officinalis L.) under foliar applications of jasmonic and salicylic acids. Biocatal. Agric. Biotechnol. 2019; doi:10.1016/j.bcab.2019.101144.

19. Saharkhiz MJ and Goudarzi T. Foliar application of salicylic acid changes essential oil content and chemical compositions of peppermint (Mentha piperita L.). J. Essent. OilBear. Plants 2014; 17 (3): 435-440. doi: 10.1080/0972060X.2014.892839.

20. Mehrpooya Zh, Abdoli M and Talebian MA. Effect of salicylic acid and yeast extract on caffeic acid derivatives production in Echinacea purpurea L. J. Med. Plants 2021; 20 (78): 36-47. doi: 10.52547/jmp.20.78.36.

21. Loc NH, Anh NHT, Khuyen LTM and An TNT. Effects of yeast extract and methyl jasmonate on the enhancement of solasodine biosynthesis in cell cultures of Solanum hainanense Hance. J. BioSci. Biotechnol. 2014; 3: $1-6$.

22. Kochan E, Szymczyk P, Kuźma Ł, Lipert A and Szymańska G. Yeast extract stimulates ginsenoside production in hairy root cultures of American ginseng cultivated in shake flasks and nutrient sprinkle bioreactors. Molecules 2017; 22 (6): 880. doi: 10.3390/molecules22060880.

23. Adams RP. Identification of essential oil components by gas chromatography/ mass spectrometry. Carol Stream, IL: Allured Publishing Corporation; 2007: 456.

24. Argyropoulou C, Deferera D, Tarantilis PA, Fasseas C and Polissiou M. Chemical composition of the essential oil from leaves of Lippia citriodora H.B.K. (Verbenaceae) at two developmental stages. Biochem. Syst. Ecol. 2007; 35(12): 831-837. doi: 10.1016/j.bse.2007.07.001.

25. Santos-Gomes PC and Fernandes-Ferreira M. Organ and season dependent variation in the essential oil composition of Salvia officinalis L. cultivated at two different sites. J. Agric. Food Chem. 2001; 49 (6): 2908-2916. doi: 10.1021/ jf001102b.

26. Rios-Estepa R, Turner GW, Lee JM, Croteau RB and Lange BM. A systems biology approach identifies the biochemical mechanisms regulating monoterpenoid essential oil composition in peppermint. Proc. Natl. Acad. Sci. USA. 2008; 105 (8): 2818-2823. doi:10.1073/pnas.0712314105.

27. Baenas N, Garcia-Viguera $\mathrm{C}$ and Moreno DA. Elicitation: A tool for enriching the bioactive composition of foods. Molecules 2014; 19(9): 13541-13563. doi: 10.3390/ molecules190913541.

How to cite this article: Motiee M, Abdoli M. Changes in essential oil composition of peppermint (Mentha x piperita L.) affected by yeast extract and salicylic acid foliar application. Journal of Medicinal Plants 2021; 20(79): 47-58.

doi: $10.52547 / j m p .20 .79 .47$ 


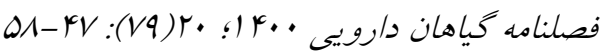

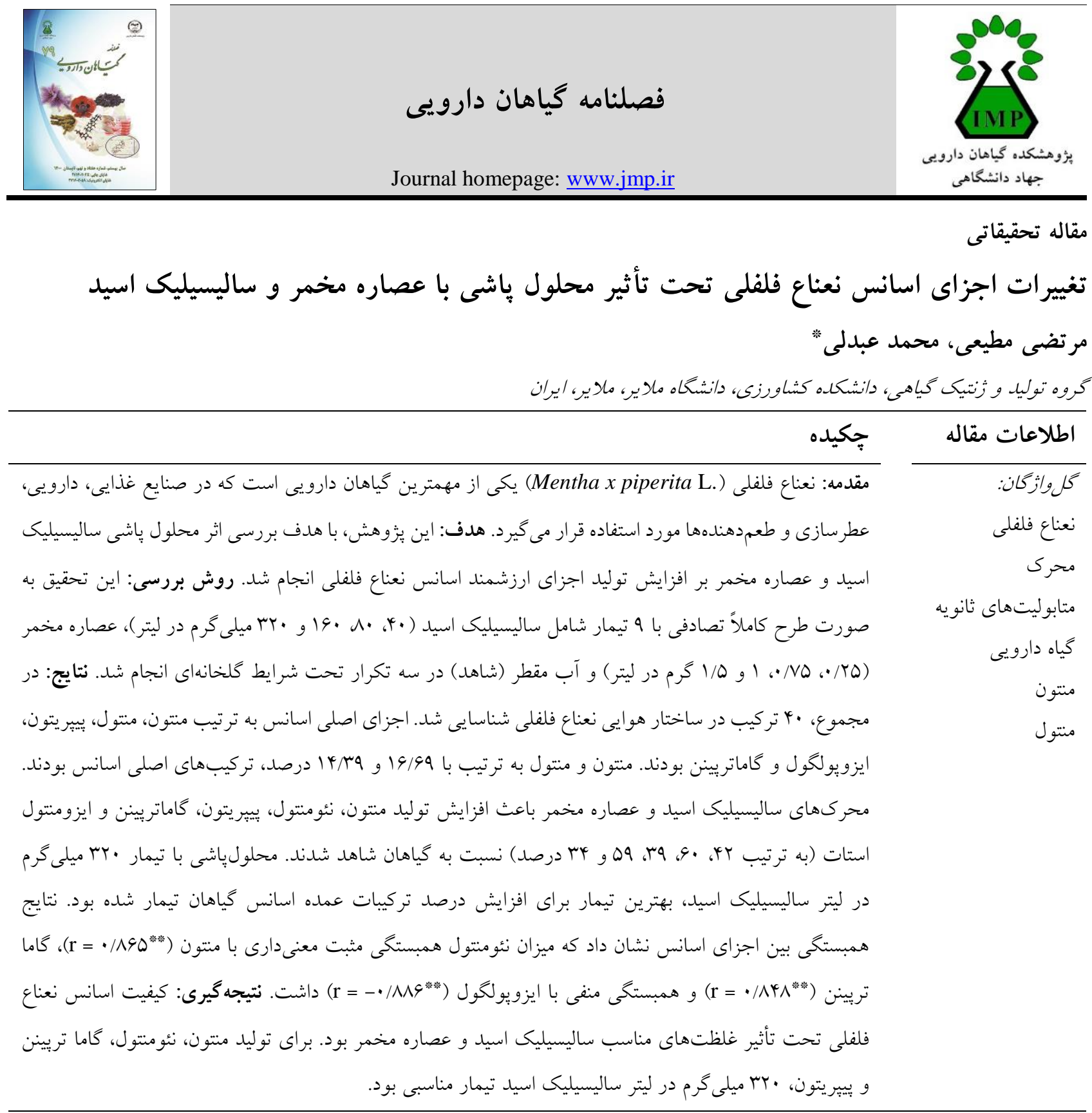

doi: $10.52547 /$ jmp. 20.79 .47

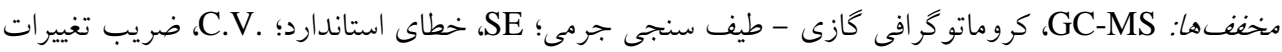

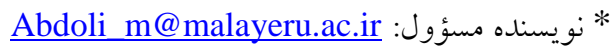

(C) 2020. Open access. This article is distributed under the terms of the Creative Commons Attribution-NonCommercial 4.0 International License (https://creativecommons.org/licenses/by-nc/4.0/) 